\title{
The Pattern of Refugee Management for Ensuring Their Rights: The Indian Approach
}

\author{
Thavamani Johnson Sampathkumar \\ Madras Christian College, Chennai, India
}

\begin{abstract}
In its short history India has hosted some of the largest refugee movements in history including the massive flows between India and Pakistan in 1947. At that time, Partition and India giving asylum to approximately 10 million refugees from the former East Pakistan (now Bangladesh) in the early 1970. Presently India has in its refugee protection Tibetans from Tibet, Tamils from Sri Lanka and Chakma from Bangladesh who have been granted protection and care and are directly assisted by the Government of India. Also refugees such as Burmese, Afghans and others are under Indian care. India is not a state party to the $1951 \mathrm{UN}$ Convention relating to the status of refugees or the 1967 protocol, nor is there any domestic law or legal procedure governing the protection of refugees. There is no binding regional agreement concerning refugees in South Asia. India continues to maintain the same for various reasons but primarily internal security. In spite of the fact that there is no any legal regime to govern the refugee protection, India has acceded to or signed all the major international human rights instruments such as International Covenant on Civil and Political Rights, 1966, International Covenant on Economic, Social Cultural Rights, 1966, Convention on the Rights of Child 1989. Indian laws that are enacted from time to time necessarily incorporate many of the international provisions so that the refugees are taken care of adequately. Further, the Indian Constitution makes no distinction between Indian nationals and others including refugees in ensuring basic human rights and freedom. Articles 14 and 21 of Indian Constitution, for example, are equally applicable to all. Of late the interventions of Indian Judiciary and Human Rights Institutions such as National and State Human Rights Commissions are praiseworthy and of paramount importance in safeguarding refugees against arbitrary actions. The role of civil societies and the media is noteworthy in this context. India adopts the principle of non-refoulement in matters pertaining to refugee protection. The Sri Lankan Tamils' case is a glaring example to substantiate the above principle. This article dwells on the pattern of refugee management in India and the issues involved in it.
\end{abstract}

Keywords: refugee management, Indian approach, refugee situations

\section{Introduction}

India's diversity, stability and relatively well established rule of law have made it a natural destination for people fleeing persecution and instability in their own countries. Within the South Asian region, India stands out as an exception of tolerant, democratic and secular government. India has historically faced numerous influxes over many millennia and the ability of these people to integrate into a multi-ethnic society and contribute peacefully to local cultures and economies has reinforced the perception of India being a country traditionally hospitable to refugees (Florina, 2004; 2006). India sharing seven land borders and one sea border

Thavamani Johnson Sampathkumar, Professor, Department of Public Administration, Madras Christian College. 
with countries in varied states of strife and war has hosted large refugee populations from neighboring countries over the years. There are no authoritative statistics on the number of people who have fled persecution or violence in their countries of origin to seek safety in India. However, because of India's porous borders and accommodative policies, it was estimated that India hosted approximately 3.5 million people in one or other form of refugees (Florina, 2004; 2006).

India's freedom in 1947 starts from accommodating refugees which means even before the adoption of 1951 UN Convention India has been managing refugees in huge numbers on its own. The partition between India and Pakistan led to the first occurrence of refugee inflow in to India in millions and India had to pass three important legislations namely Administration of Evacuee Property Act 1950, the Evacuee Property (Separation) Act 1951, and the Displaced Persons (Compensation and Rehabilitation) Act 1954 by which justice was established to the refugees from both sides.

After China quashed Tibetan Rebellion in 1959, India had to accommodate the Tibetan religious leader, Thalai Lama and his followers in thousands and gave them a separate territory namely Daramsala to govern themselves. Daramsala is a city and a municipal council in Kangra district in the Indian state of Himachal Pradesh. There are around 1.5 million Tibetan populations in India today since 1959 when China quashed Tibetan Rebellion. The question of Tibet is still an unresolved issue despite the fact that India has assured China of Tibet is its integral part. India had to pay a price for accommodating Tibetans and its leader in the form of 1962 Chinese aggression. Since then, there is constant rift between India and China over border issues and India is compelled to focus on its defense and spending huge funds to defend its borders.

Then followed the civil war between East and West Pakistan that lasted over two decades as a result of which India had to accommodate huge number of Bangladeshi refugees. Finally India had to intervene in the war inevitably in 1971 towards its successful end settling a major issue in this region. Consequently Bangladesh was born and sequent to it. India is currently facing continuous terrorist attacks from Pakistan borders.

Srilankan problem is yet another major issue in this region wherein India had to intervene to end the 30 year long civil war between Sri Lankan Government and its militant separatist force Liberation Tigers of Tamil Eelam (LTTE). During the war, over 1.2 million Srilankan Tamils fled from their country and sought asylum in India and majority of them were accommodated in Tamilnadu, a southern state in India. Again India, in the process, had to pay a heavy price for it in the form of killing of its former Prime Minister Mr. Rajiv Gandhi by LTTE militants within Indian Borders. Despite this tragic loss, India is still negotiating with Srilankan Government to initiate democratic process in the war torn Northern Province of Srilanka. With the diplomatic efforts with Srilankan Government, a favorable political atmosphere was created in Srilanka and thereby Srilankan Tamils are repatriated back to Srilanka from various refugee camps in Tamilnadu. India continues to offer financial and rehabilitation assistance to the returnees besides constantly holding dialogue with Srilankan Government for implementing the 12th amendment of Indo-Srilankan accord for a lasting solution.

In the last 67 years, India as a sovereign nation has always played a key role in genuinely settling disputes and civil wars in this region besides accommodating refugees including Burmese, Afghans, Chakmas, Iranians, Sudanese, and Somalians (A Pocket Guide to Refugees, 2004). In the long history of managing refugee problem, there is neither a single case denying refugee protection abruptly to any nor did India act against the International Customary Law "Principle of non-refoulement" unless and until there was a serious security threat. 


\section{Present Status}

Owing to several reasons such as population, security, political, financial and socio-cultural, Government of India is yet to pass a separate legislation in Parliament. Further, like any other South Asian nation, India is a signatory neither to $1951 \mathrm{UN}$ convention relating to the status of Refugees nor to its 1967 protocol (Vijayakumar, 2001, p. 7). However, India's management of refugees is an indigenous and futuristic oriented. Currently, the Refugees are managed by three broad categories. One is that the refugees who are received and protected by the Indian Government directly. The second is those refugees who are managed by the United Nations High Commissioner for Refugees (UNHCR) and protected with their financial and other humanitarian assistance. And the third category is the refugees who are in the lot neither recognized by the Indian Government and nor by UNHCR but have entered India and assimilated into local community (Chimni, 1994).

India accords status to the refugees beyond the scope of 1951 convention or any other international instruments. It treats a refugee genuinely like any other human being on its soil within its limitations. Refugee in real sense is a seeker of protection when one's life is in danger. In the socio-psychological dimension, it is improper to label a person as "refugee" within a nation or in a foreign land. One should not live in refugee camps for decades detrimental to human value and dignity. At times warring nations endlessly prolong wars taking advantage of asylum providing nations. Interestingly sometimes the internal civil wars are perpetuated by other nations for selling their arms and ammunitions. Warring nations should be pressurized to end civil wars through international efforts but unfortunately there is absence of an effective mechanism legal or otherwise.

\section{Legal Provisions}

The word refugee does not find mention in any one of the Indian documents. However, the Constitutional and statutory provisions which are now in vogue can cater to the needs of refugees and asylum seekers. Refugees and asylum seekers in India are viewed as foreigners and dealt by the Foreigners Registration Act, 1946. Of course there are serious criticisms against this practice from various quarters within and outside (Thames, 1999). However, to establish the genuineness of refugee status India applies the broader meanings and definitions of a "refugee" given in the 1951 Convention and also the extended definitions of the term spelt out in other regional or international instruments. ${ }^{1}$

The fundamental rights enshrined in the Indian Constitution for protecting life, liberty, equality and dignity are applicable to all human beings irrespective of the fact whether they are citizens or others (Dhavan, 1996). These include the protection of the equality clause (Article 14) and the life, liberty and due process provisions (Article 21) of the Indian Constitution. While Article 14 guarantees equality before the law and the equal treatment of the law, classifications of persons into separate and distinct classes based on intelligible differentia with a nexus to the object of the classification are allowed. Article 21 protects any person from the deprivation of his life or personal liberty except according to procedure established by law. From a rather staid interpretation of this provision, the Supreme Court has radically reinterpreted this Article to include a substantive due process of law to be followed for any state action impinging on life and personal liberty. So the foreigners are equally entitled to the right against deprivation of life, bodily integrity and dignity and also they enjoy to a certain extent, the right against executive action sans procedural due process (Hathaway, 2003).

\footnotetext{
${ }^{1}$ Article 1-A(2) of the Convention Relating to the Status of Refugees, 1951.
} 
By law and practice India remains to be a rule of law state and has not slipped even once from its democratic path of governance from its independence. In other words there has always been only constitutionally elected governments in power at the Union level whether it is coalition (multiparty) or single party. There is an independent judiciary which means free and fair justice to all and Indian Judiciary has done a commendable job in dispensation of justice particularly in matters related to refugees (N. D. Panchali verses State of Punjab, Zothansanguli verses State of Manipur, Bogiv verses Union of India, Dr. Malavika Karlekar verses Union of India are some of the leading cases where the High Courts and Supreme Court have delivered land mark judgments in favor of refugees) (The Times of India (Daily), 2013). The National and State Human Rights Commissions investigate and make strong recommendations to the governments concerned which are liable to be tabled in the house for discussion and governments are obligated for submitting Action-Taken Reports to the Parliament. Right to Information Act, Development of Information Technology and Investigative Media are all part of supportive environment whereby information about refugees cannot be suppressed at all. The role of UNHCR, though limited in India, is noteworthy and the UNHCR officials join hands with the National and State Governments, Human Rights Commissions, Courts and Civil Societies in India to extend and ensure all the possible Rights to which refugees are entitled in accordance with UN Convention, 1951 and other international instruments. ${ }^{2}$

\section{Issues and Challenges Today}

Despite the fact that the core instruments of refugee protection 1951 UN Convention, the establishment of UNHCR etc. are relevant even today, they have been under considerable strain in recent years. A growing number of states have questioned the continued relevance of these core instruments, especially the 1951 Convention (Millbank, 2000). Critics have argued that the 1951 Convention is Euro-centric, inflexible, outdated, and not capable of addressing the complexities of today's global refugee crisis. States now point to a number of contemporary challenges left unaddressed by the 1951 Convention such as the changing nature of asylum, the mixing of asylum seekers and economic migrants, the range of security concerns associated with refugee movements, the costs to states associated with granting asylum and the growing scale and globalization of the problem of forced migrants.

In contrast, supporters of the 1951 Convention argue that while the Convention is not perfect, it continues to provide an important and legitimate foundation for the international refugee protection regime. Significant gaps in the international refugee protection regime do exist. Indeed, while the core objectives of protection and solutions have been recognized since 1950, they appear to be as difficult as ever to realize.

Over the past 20 years, Western states - especially Western European states - have introduced measures to reduce the number of individuals seeking asylum on their territory. These measures included non-arrival policies, diversion policies, an increasingly restrictive application of the 1951 Convention and a range of deterrent policies such as detention of asylum seekers and the denial of social assistance. As a result, a core group of Western states have systematically eroded the principle and practice of asylum to the point where some states like the UK openly called for the scrapping of the 1951 Convention and a new international refugee regime premised on containing refugees within their region of origin (Suryanarayan, 2001).

These moves to contain refugees in their regions of origin coupled with a rise in global refugee numbers in

\footnotetext{
${ }^{2}$ UNHCR helps first group of Sri Lankan Refugees return by ferry from India, News Stories, October 12, 2011.
} 
the early 1990s and the problematic response by the international community has placed a significant strain on asylum countries in the South. As refugee numbers continued to rise in the 1990s, states in the global South began to place restrictions on asylum. Some states limited the quantity of asylum they offered to refugees, by closing their borders to prevent arrivals, by pushing for the early and often unsustainable return of refugees to their country of origin and in exceptional cases, forcibly expelling entire refugee populations.

More generally, states have been placing limits on the quality of asylum they offer to refugees, by denying them the social and economic rights contained in the 1951 Convention such as freedom of movement and the right to seek employment. Many states in the South now require refugees to remain in isolated and insecure refugee camps cut-off from the local community and fully dependent on dwindling international assistance.

\section{Protracted Refugee Situations (PRS)}

In fact, refugees are spending longer periods in exile, and increased attention is now being paid to the rise of these so-called protracted refugee situations. Such situations are the result of a political failure to ensure that refugees have timely access to durable solutions. Their negative consequences are often exacerbated by the inadequate levels of protection, assistance and social and economic opportunities available to refugees in many host countries.

While prolonged displacement has a significant impact on the human rights of refugees, it also has important consequences on security not only in the host countries but also regionally and internationally. In particular, refugees emanating from states such as Afghanistan and Somalia have been identified as a potential source of instability for host states because of their possible on-going attachment to armed groups of non-state actors engaged in insurgent or terrorist activities. In this way, prolonged refugee situations, left unaddressed, may undermine peace building efforts in the country of origin (Crawley, 1993, p. 5).

\section{Conclusion}

Firstly, the universal approach should continue to resolve the refugee issues world over through UN. There is no doubt that the UNHCR has done a commendable job thus far but the need of the hour is that it must be reorganized and strengthened to operate more closely with the host countries taking into account the local conditions rather than applying only universal standards. It is time that there should be another UN Convention for refugees in the changed context of globalized world, marketed economies and enhanced democratization and social movements. Secondly, regional level mechanism can take shape so that they can be more realistic and effective. In these situations localized approach would be more pragmatic and also facilitate and encourage regional cooperation and burden sharing that is appropriate in scale, scope and duration in responding to the regional refugee problem. Thirdly, individual nations particularly the host countries including India can also think of establishing their own clear cut broad based statutory laws to deal with the problems of refugees depending on their national and regional environment.

In case of India, already it is on the move to enact a law. There are increasing pressures from all quarters including courts to have a separate law (Loescher, Milner, Newman, \& Troeller, 2008). One must take into account that the Delhi Courts' observation. The Court observed that "It is unfortunate that in spite of having an impressive record of welcoming refugees, we do not have a national law in place to cater for the specific needs of this class". In his order, the Metropolitan Magistrate said that the need for enacting comprehensive legislation to deal exclusively with the problems of refugees had become imperative and pursuant to extensive 
deliberations a model national law namely "The Refugee and Asylum Seekers" (Protection) Bill, 2006 was drafted but "it is unfortunate that despite its having been drafted after due deliberations and after various rounds consultations by eminent jurists, this bill has not seen the light of the day" (Venkatesan, 2015).

In the light of the above discussion, it is high time that India enacts a separate law for refugee protection according to its local and regional needs. It should also develop a mechanism to implement the law effectively. The law should be enacted in such a way that it not only fills the legal vacuum in the refugee regime but also prevents the breeding of refugees in and around India. A broader understanding is required among national and as well as regional leaders.

\section{References}

A Pocket Guide to Refugees. (2004). External Relations Publications. UNHCR, New Delhi.

Chimni, B. S. (1994). The legal conditions of refugees in India. Journal Refugee Studies, 7(4), 394-398.

Crawley, H. (1993). The refugee crisis facing Western Europe. Research Paper 11. University of Sussex, Falmer, Brighton.

Dhavan, R. (1996). Treaties and people: Indian reflections. Journal of the Indian Law Institute, 39, 1-46.

Florina, B. (2004). India: A national refugee law would equalize protection, refugee international.

Florina, B. (2006). Country operations plan for India. United Nations High Commissioner for Refugees.

Hathaway, J. (2003). The emerging politics of non entr'e. Refugees, 91, 40-44.

Loescher, G., Milner, J., Newman, E., \& Troeller, G. (Eds.). (2008). Protracted refugee situations: Political, human rights and security implications. Tokyo: UN University Press.

Millbank, A. (2000). The problem with the 1951 refugee convention. Research Paper, Social Policy Group 5.

Suryanarayan, V. (2001). The need for National Refugee Law. ISIL Year Book of International Humanitarian and Refugee Law, No.5, New Delhi.

Thames, K. (1999). India's failure to adequately protect refugees. Country Report on India from the US Committee for Refugees. Retrieved from http://www.wcl.american.edu

The Times of India (Daily). (2013). Court stresses need to consider rights angle in refugee cases. Retrieved from http://articles.timesofindia.indiatimes.com/2013-07-13/kochi/405534

Venkatesan, J. (2015). Magistrate: How can court become party to persecution of refugees? The Hindu (Daily). Retrieved from http://www.thehindu.com/news/national/article2471121.ece

Vijayakumar, V. (2001). A critical analysis of refugee protection in South Asia. Refugee, 19(2), 6-16. 